\title{
Studi Eksperimen Pengaruh Penggunaan Koh Terhadap Performa Generator HHO Tipe Dry Cell Dengan Dimensi Setiap Plat 3.046,59 Mm²
}

Nofriyandi. R., S.Pd., MT

Jurusan Teknik Mesin, Universitas Dharma Andalas, Kampus Simpang Haru Sawahan - Padang

\section{INFORMASI ARTIKEL}

\section{Sejarah Artikel:}

Diterima Redaksi: 07 Februari 2017

Revisi Akhir: 01 Maret 2017

Diterbitkan Online: 01 April 2017

\section{KATA KUNCI}

Generator

Dry cell

Experiment

HHO gas

Efficiency

\section{KORESPONDENSI}

E-mail: nofriyandi.pnp@gmail.com

\begin{abstract}
A B S T R A C T
This research is aimed to analyze efficiency and produced $\mathrm{HHO}$ gas from $\mathrm{HHO}$ type dry cell generator. The experimental apparatus of a generator consists of 4 cells and four neutral plates for each cell is produced. The generator plate used in the electrolysis process has dimension $30.29 \mathrm{~mm} 2$. The total area of plate is $70 \mathrm{~mm} \times 70 \mathrm{~mm}$ and it has a single hole with diameter $12 \mathrm{~mm}$ located in the middle of the plate. To collect the data, the generator has been operated for 2 hours. The efficiency of the generator is evaluated by addition of 5, 7 and 9 gram $\mathrm{KOH}$ into the cell. It was shown from the experiment that, the average of HHO gas resulting from 5 gram $\mathrm{KOH}$ is $6.45 \mathrm{ml} / \mathrm{s}$ with efficiency $89.39 \%$. Meanwhile, for 7 and 9 gram $\mathrm{KOH}$, the average $\mathrm{HHO}$ gas are $9.31 \mathrm{ml} / \mathrm{s}$ and $12.92 \mathrm{ml}$ with efficiency $72.29 \%$ and $83.49 \%$, respectively.
\end{abstract}

\section{PENDAHULUAN}

Hasil pembakaran bahan bakar fosil yang terdiri dari campuran karbon, hidrokarbon, oksigen dan hidrogen dapat menghasilkan nilai polutan yang besar sehingga berbahaya bagi lingkungan. Dalam pencagahan besarnya efek polutan tersebut, berbagai peneliti terus melakukan penelitian dan pengembangan.

Untuk mengurangi polusi udara yang di sebabkan oleh pembakaran bahan bahan bakar fosil tidak sempurnah, terutama pada kendaraan telah di lakukan berbagai macam cara. Cara yang paling sering dilakukan adalah dengan melakukan penelitian bagaimana agar terjadi pembakaran sempurnah pada kendaraan. Namun karakteristik dari pembakaran bahan bakar fosil lebih cenderung menguluarkan racun dalam kondisi pembakaran apapun yaitu, baik dalam kondisi pembakaran tidak sempurnah maupun pembakaran sempurna.

Perkembangan dan penggunaan biodiesel dan bioethanol masih belum optimal karena beberapa faktor diantaranya adalah sumber bahan bakunya belum memadai secara kuantitas dan kualitas, sebagian dari bahan bakunya adalah bahan pangan yang masih mungkin mengganggu ketersediaan bahan pangan, serta kesiapan dari segi budi daya, kesiapan teknologi proses, kesiapan saranaprasarana pemasarana. Bahan bakar yang dihasilkan 
dari pemanfaatan energi dengan cara elektolisa air murni menjadi bahan bakar atau gas HHO dinilai sebagai bahan bakar masa depan yang ramah lingkungan dan efisien dikarenakan bahan bakunya yang sangat mudah di temukan serta menghasilkan emisi yang lebih ramah lingkungan pada saat terjadi proses pembakaran, di karenaan properties gas HHO tidak memiliki nilai karbon yang memicu terjadinya emisi gas buang yang beracun. Selanjutnya gas hidrogen mempunyai nilai energi lebih besar dari pada bahan bakar gasoline yang biasa di gunakan sebagai bahan bakar pada kendaraan. Perbandingan bahan bakar gasoline dengan hydrogen dapat dilihat pada Tabel 1.

Penelitian ini bertujuan agar dapat mengetahui persentasi dari jumlah dari gas $\mathrm{HHO}$ yang di hasilkan. Selanjutnya menghitung nilai dari efisiensi generator HHO type dry agar dapat mengatahui seberapa besar performance generator
HHO type dry cell terhadap daya yang dibutuhkan. Variasi dalam setiap penelitian hanya melihat perbedaan hasil dari jumlah $\mathrm{KOH}$ yang di berikan yaitu 5 gram, 7 gram dan 9 gram $\mathrm{KOH}$. Pengambilan data dilakukan dengan melihat secara langsung banyaknya gas $\mathrm{HHO}$ yang di peroleh dalam setiap 500 milli liter/detik. Setiap pengujian dilakukan selama 120 menit pada setiap variasi.

Pada penelitian Nofriyandi. R (2016) meneliti tentang pengaruh penggunaan $\mathrm{KOH}$ terhadap performance generator $\mathrm{HHO}$ tipe dry cell berdiamensi $3.316 \mathrm{~mm}^{2}$ dengan 3 cell dan 4 plate netral menggunakan 5 gram $\mathrm{KOH}$ menghasilkan gas $\mathrm{HHO} 7,181 \mathrm{ml} / \mathrm{s}$ efisiensi 91,3\%. 7 gram $\mathrm{HHO}$ menghasilkan gas $\mathrm{HHO} 11,128 \mathrm{ml} / \mathrm{s}$ efisiensi 87,3\%. 9 gram $\mathrm{KOH}$ menghasilkan gas $\mathrm{HHO}$ $12,283 \mathrm{ml} / \mathrm{s}$ efisiensi $86,8 \%$. Pada peneliti Sugeng

Tabel 1. Perbandingan bahan bakar gasoline dengan hydrogen

\begin{tabular}{|c|c|c|}
\hline \multicolumn{3}{|l|}{ The properties of hydrogen } \\
\hline Properties & Unleaded gasoline & Hidrogen \\
\hline $\begin{array}{l}\text { Autoignition temperature } \\
\text { (K) }\end{array}$ & $533-733$ & 858 \\
\hline $\begin{array}{l}\text { Minimum ignition energy } \\
\text { (mJ) }\end{array}$ & 0.24 & 0.02 \\
\hline $\begin{array}{l}\text { Flammability limits (volume } \\
\% \text { in air) }\end{array}$ & $1.4-7.6$ & $4-75$ \\
\hline $\begin{array}{l}\text { Stoichiometric air-fuel ratio } \\
\text { on mass basis }\end{array}$ & 14.6 & 34.3 \\
\hline $\begin{array}{l}\text { Limits of flammability } \\
\text { (equivalence ratio) }\end{array}$ & $0.7-3.8$ & $0.1-7.1$ \\
\hline $\begin{array}{l}\text { Density at } 16 \_C \text { and } 1.01 \\
\text { bar }(\mathrm{kg} / \mathrm{m} 3)\end{array}$ & $721-785$ & 0.0838 \\
\hline $\begin{array}{l}\text { Net heating value }(\mathrm{MJ} / \mathrm{kg}) \\
\text { Flame velocity }(\mathrm{cm} / \mathrm{s})\end{array}$ & 43.9 & 119.93 \\
\hline $\begin{array}{l}\text { Quenching gap in NTP air } \\
(\mathrm{cm}) \\
\text { Diffusivity in air }(\mathrm{cm} 2 / \mathrm{s})\end{array}$ & $\begin{array}{l}37-43 \\
0.2\end{array}$ & $\begin{array}{l}265-325 \\
0.064\end{array}$ \\
\hline $\begin{array}{l}\text { Research octane number } \\
\text { Motor octane number }\end{array}$ & 0.08 & 0.63 \\
\hline Flashpoint & 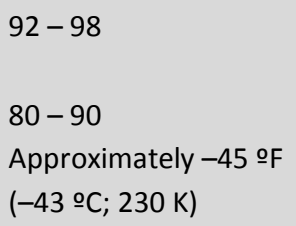 & $\begin{array}{l}130 \\
- \\
<-423 \text { o } \mathrm{F}(<-253 \\
\text { ㅇ } ; 20 \mathrm{~K})\end{array}$ \\
\hline
\end{tabular}

(Sumber: International journal of hydrogen energy 35 (Ali Can Yilmaz, Erinc, Uludamar, Kadir Aydin 2010) 11366 - 11372 dan hydrogen fuel cell engines and related technologies: Rev 0, December 2001) 
Heri Purnomo dan Djoko Sungkono (2014), meneliti tentang komparasi penghasilan $\mathrm{HHO}$ pada generator tipe $d r y$ dengan susunan kerucut diameter lubang $7 \mathrm{~mm}$ dan $10 \mathrm{~mm}$ terpasang vertikal dengan nilai laju prduksi tertinggi pada diameter $7 \mathrm{~mm}$ sebesar 10,5 ml/s serta efisiensi tertinggi 49,57\%.

Dari hasil penelitian diatas penggunaan generator HHO 4 cell dengan 4 plate netral dibandingkan dengan penelitian Nofriyandi sebelumnya yaitu 3 cell dengan 4 plate netral terjadi peningkatan laju produksi sebesar $0,637 \mathrm{ml} / \mathrm{s}$ pada penambahan 9 gram $\mathrm{KOH}$, namun terjadi penurunan efisiensi pada generator. Pada penelitian Sugeng dan Djoko Sungkono, terjadi peningkatan laju produksi sebesar $2,42 \mathrm{ml} / \mathrm{s}$ serta peningkatan efisiensi sebesar $33,92 \%$.

Hasil dari penelitian ini diharapkan mampu memberikan kemudahan bagi para peneliti berikutnya dalam pengaplikasian bahan bakar $\mathrm{HHO}$ pada kendaraan sepeda motor, karna dari hasil pengujian yang diperoleh dapat ditentukan penggunaan terbaik pada aplikasi kendaraa motor dalam setiap variasi. Secara spesifik, tujuan dari penelitian ini adalah:

a. Untuk mengetahui besarnya arus listrik yang dibutuhkan, laju produksi gas $\mathrm{HHO}$ serta efisiensi pada generator $\mathrm{HHO}$ selama

\begin{tabular}{|c|c|}
\hline Informasi dan sifat-sifat \\
\hline Nama sistematis \\
\hline Nama alternatif & Aqua,dihidrogen monoksida, Hidrogen \\
hidroksida
\end{tabular}

Gambar 1. Keterangan umum unsur air percobaan dengan baterai 13 volt. Menggunakan plat 4 cell 4 plate netral dimensi $3.046,59 \mathrm{~mm}^{2}$.

b. Untuk mengetahui mana yang terbaik untuk di aplikasikan pada kendaraan dari menggunakan plat 4 cell 4 plate netral dimensi $3.046,59 \mathrm{~mm}^{2}$.

Batasan masalah yang digunakan dalam penelitian ini adalah sebagai berikut:

a. Hasil percobaan hanya berlaku untuk generator HHO tipe kering (dry) dengan elektroda plat stainless steel tipe $316 \mathrm{~L}$ dengan luas permukaan yang bekerja aktif saat elektrolisi $3.046,59 \mathrm{~mm}^{2}$.

b. Menggunakan larutan elektrolit KOH 5 gram, 7 gram dan 9 gram pada1 liter aquades.

c. Analisa dilakukan pada generator HHO meliputi daya yang dibutuhkan generator $\mathrm{HHO}$, laju produksi gas $\mathrm{HHO}$ dan efisiensi generator HHO.

\section{KAJIAN PUSTAKA}

Jika air dipanaskan akan berubah bentuk menjadi uap air atau gas dengan simbol $\mathrm{H}_{2} \mathrm{O}_{(\mathrm{g})}$. Jika air dipecah dengan menggunakan energi yang sesuai, maka akan terurai menjadi gas $\mathrm{H}_{2(\mathrm{~g})}$ dan gas $\mathrm{O}_{2(\mathrm{~g})}$. Gas yang keluar ketika air dipanaskan bukan gas hidrogen. Air hanya dapat dipecah menjadi gas hidrogen dan gas oksigen (sebagai bahan penyusunnya) dengan teknik tertentu. Banyak teknik untuk memecah air menjadi gas $\mathrm{H}_{2(\mathrm{~g})}$ dan gas $\mathrm{O}_{2(\mathrm{~g})}$ yaitu dengan menggunakan energi nuklir dan elektrolisis. Cara elektrolisis sangat mungkin dilakukan, karena selain aman, cara ini juga mudah untuk dilakukan. Elektrolisis yaitu proses yang memerlukan energi listrik untuk terjadinya reaksi kimia, seperti penguraian air menjadi gas hidrogen dan gas oksigen.

\section{METODOLOGI}

Metode pada penelitian ini dilakukan secara eksperimental. Pengujian langsung pada alat yang telah di rancang, sesuai dengan ukuran yang telah ditentukan dalam pengujian. Generator HHO dipasang secara vertikal dengan menggunakan 4 
cell, pada masing-masing cell terdiri dari 4 plat netral. Luas permukaan yang bekerja pada masingmasing plat di batasi oleh $O$-ring seals dengan ukuran $\emptyset$ luar $60 \mathrm{~mm}$.

Variasi hasil data uji diperoleh dari jumlah banyaknya penggunaan $\mathrm{KOH}$ yaitu, 4, 5 dan 7 gram KOH. Pegujian dilakukan selama 120 menit agar mendapatkan hasil yang lebih akurat. Sumber energi di peroleh dari enegi baterai (DC) yang terpasang langsung carger dari listrik PLN guna menjaga kestabilan energi baterai.

Parameter yang berperan dalam menentukan unjuk kerja generator $\mathrm{HHO}$ adalah sebagai berikut:

1. Daya Generator $\mathrm{HHO}\left(\mathrm{P}_{\mathrm{HHO}}\right)$, [Watt]

Perumusan untuk daya yang dibutuhkan adalah sebagai berikut:

$$
P=V x I
$$

\section{Dimana:}

$$
\begin{aligned}
& \mathrm{P}=\text { daya generator } \mathrm{HHO} \text { (watt) } \\
& \mathrm{V}=\text { beda potensial/ voltase (volt) } \\
& \mathrm{I}=\text { arus listrik (ampere) }
\end{aligned}
$$

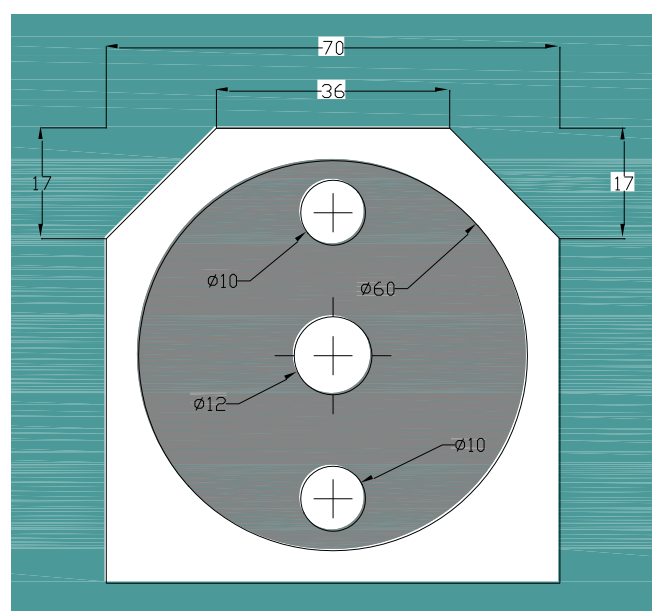

Gambar 2. Ukuran Plate Netral Generator HHO

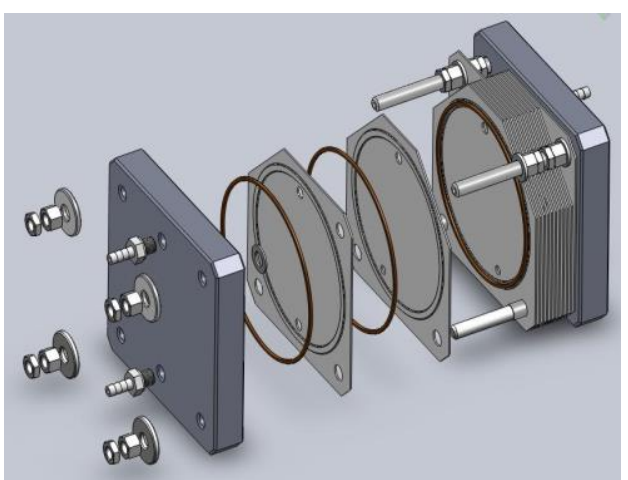

Gambar 3. Cara Pemasangan Generator HHO

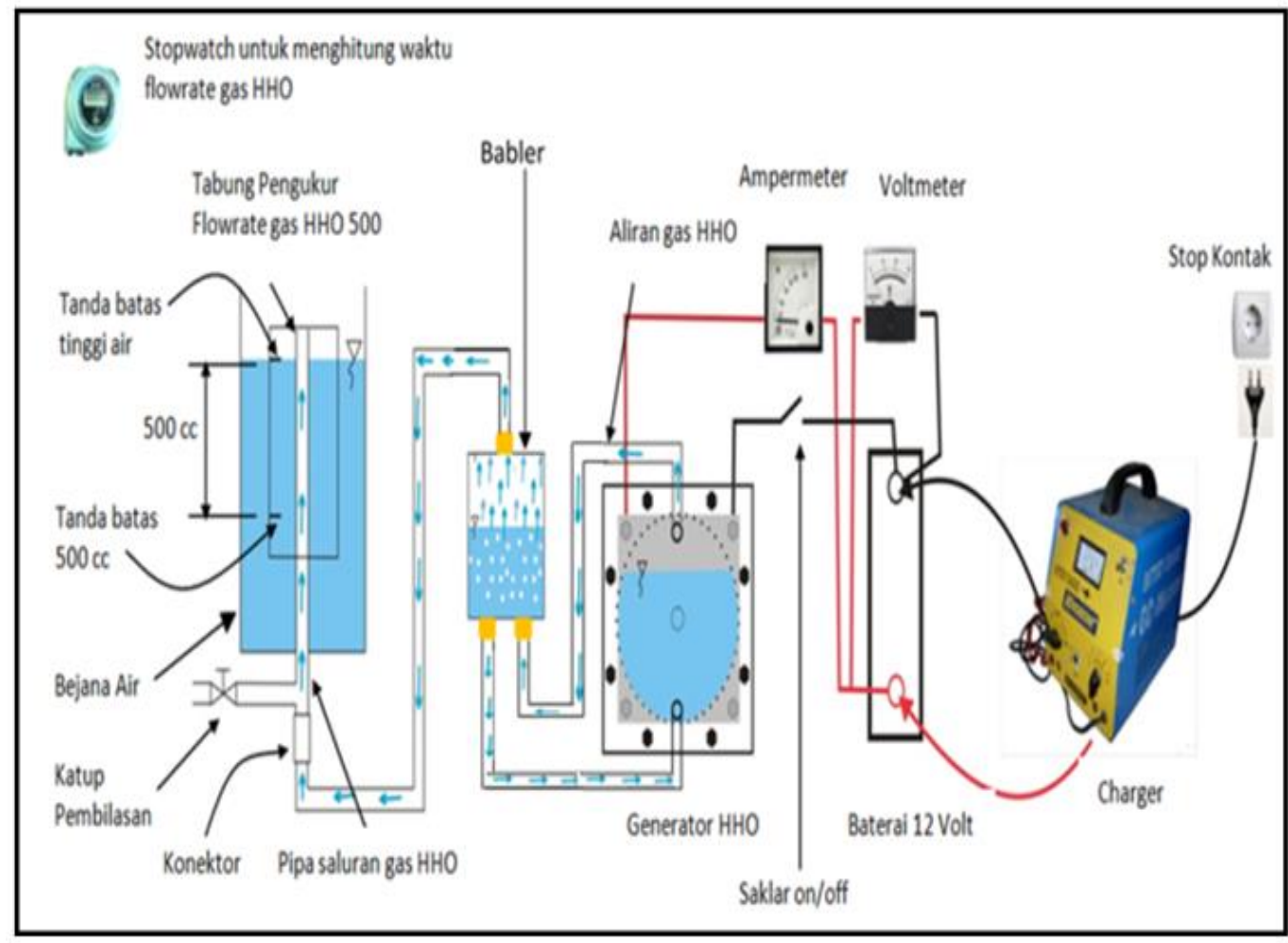

Gambar 4. Skema Pengujian Generator HHO 
2. Laju Produksi Gas $\mathrm{HHO}\left(\dot{m}_{\mathrm{HHO}}\right)$

Menghitung flowrate gas HHO dengan persamaan berikut ini:

$\dot{m}=Q \times \rho$

Dimana:

$\dot{\mathrm{m}}=$ Laju Produksi Gas HHO $(\mathrm{Kg} / \mathrm{s})$

$\mathrm{Q}=$ Debit Produksi gas $\mathrm{HHO}\left(\mathrm{m}^{3} / \mathrm{s}\right)$

$\rho=$ Massa Jenis HHO $\left(\mathrm{Kg} / \mathrm{m}^{3}\right)$

Persamaan debit Produksi gas HHO:

$Q=\frac{V}{t}$

Dimana :

$\mathrm{V}=$ Volume gas Terukur $\left(\mathrm{m}^{3}\right)$

$\mathrm{t}=$ Waktu produksi gas $\mathrm{HHO}$

\section{Efisiensi Generator $\mathrm{HHO}\left(\eta_{н н о}\right),[\%]$}

Efisiensi dihitung agar mengetahui optimalitas generator selama bekerja, yaitu dilihat dari perbandingan jumlah energi yang masuk dan terpakai dalam sistim kerja dengan energi yang dihasilkan atau energi keluar. Adapun persamaan efisiensi secara umum adalah sebagai berikut:

$\eta=\frac{\text { Energi yang berguna (output) }}{\text { Energi yang diberikan (input) }} \times 100 \%$

Energi yang terpakai (input) merupakan komponen yang bekerja dalam proses elektrolisa pada generator gas $\mathrm{HHO}$, dalam hal ini adalah entalpi generator, entalpi bernilai positif karena reaksi pada generator gas $\mathrm{HHO}$ adalah reaksi endoterm atau reaksi yang menyerap panas untuk menghasilkan produk. Sedangkan energi yang berguna (output) adalah energi yang diberikan dari generator. Nilai input yaitu nilai entalpi gas ideal.

$\mathrm{H}_{2} \mathrm{O}_{(\mathrm{l})} \rightarrow \mathrm{H}_{2(\mathrm{~g})}+1 / 2 \mathrm{O}_{2(\mathrm{~g})}=+285,84 \times 10^{3} \mathrm{~J} / \mathrm{mol}$

Lalu untuk nilai energi ikatan yang dibutuhkan dapat diketahui melalui rumusan dibawah ini:

$p \times V=n \times \bar{R} \times T$
Jika persamaan (5) ditinjau persatuan waktu, maka:

$p \times \dot{V}=\dot{n} \times \bar{R} \times T$

$\dot{\eta}=\frac{p \times \dot{V}}{\bar{R} \times T}$

Dimana:

$\mathrm{p}=$ Tekanan Gas ideal $(1 \mathrm{~atm}=100 \mathrm{kPa})$

$\dot{V}=$ Volume per satuan waktu (liter/s)

$\bar{R}=$ Konstanta Gasideal (8.314472 J/mol.K)

$\dot{n}=$ Mol per satuan waktu $(\mathrm{Mol} / \mathrm{s})$

$\mathrm{T}=298 \mathrm{~K}(\mathrm{STP})$

output $=P_{\text {gen }}=V \times I$

Maka nilai Effisiensi dari generator gas HHO:

$\eta=\frac{\Delta h f \times \dot{\eta}}{(V \times I)} \times 100 \%$

\section{HASIL DAN PEMBAHASAN}

Pada Gambar 5 ditampilkan hubungan arus listrik yang dihasilkan terhadap waktu dengan variasi harga berat dari KOH. Dari Gambar 5 terlihat bahwa peningkatan kecepatan proses elektrolisis ini disebabkan oleh berkurangnya hambatan antara cairan elektrolit dan elektroda, dengan tegangan listrik yang sama seiring mengecilnya hambatan maka jumlah arus listrik akan semakin besar.

Hasil pengujian generator pada Gambar 5 di atas dilakukan selama 120 menit. Dari hasil uji terlihat bahwa jumlah campuran larutan elektrolit $(\mathrm{KOH})$ mempengaruhi besarnya arus listrik yang dihasilkan. Semakin besar jumlah $\mathrm{KOH}$ yang digunakan semakin besar jumlah arus listrik yang dihasilkan untuk proses kerja pada generator HHO, ini disebabkan oleh berkurangnya hambatan antara cairan elektrolit dan elektroda, dengan tegangan listrik yang sama seiring mengecilnya hambatan maka jumlah arus listrik akan semakin besar. Larutan elektrolit akan mempengaruhi besarnya energi yang dibutuhkan agar bias terjadi reaksi kimia dalam larutan. Larutan elektrolit yang mengandung ion-ion (anion dan kation) berguna 
sebagai penghantar arus listrik, hal inilah yang mempengaruhi besarnya arus listrik. Efek dari arus listrik yang semakin besar menyebabkan pergerakkan ion-ion tersebut akan semakin cepat. Semakin cepat pergerakan ion-ion akan menimbulkan gesekkan antara ion yang semakin besar sehingga temperatur larutan semakin tinggi dan semakin lama suatu larutan bereaksi menyebabkan kondisi larutan akan semakin jenuh hal inilah yang menyebabkan berkurangnya nilai arus listrik saat melakukan pengujian pada menit ke 100.
Pada Gambar 6 diperlihatkan hubungan antara laju produksi gas $\mathrm{HHO}$ generator 4 cell terhadap lamanya waktu pengujian. Hasil dari elektrolisis air pada generator gas $\mathrm{HHO}$ tipe dry cell ini produk utamanya ialah gas hidrgen $\left(\mathrm{H}_{2}\right)$ dan ksigen $\left(\mathrm{O}_{2}\right)$ atau dapat dituliskan sebagai gas HHO. semua data yang tertulis dalam grafik adalah gas $\mathrm{HHO}$, artinya terdiri dari gas $\mathrm{H}_{2}$ dan gas $\mathrm{O}_{2}$, sehingga untuk mengetahui seberapa banyak gas HHO yang dihasilkan oleh generator gas HHO tersebut dapat dilihat dari laju produksi gas yang dihasilkan.

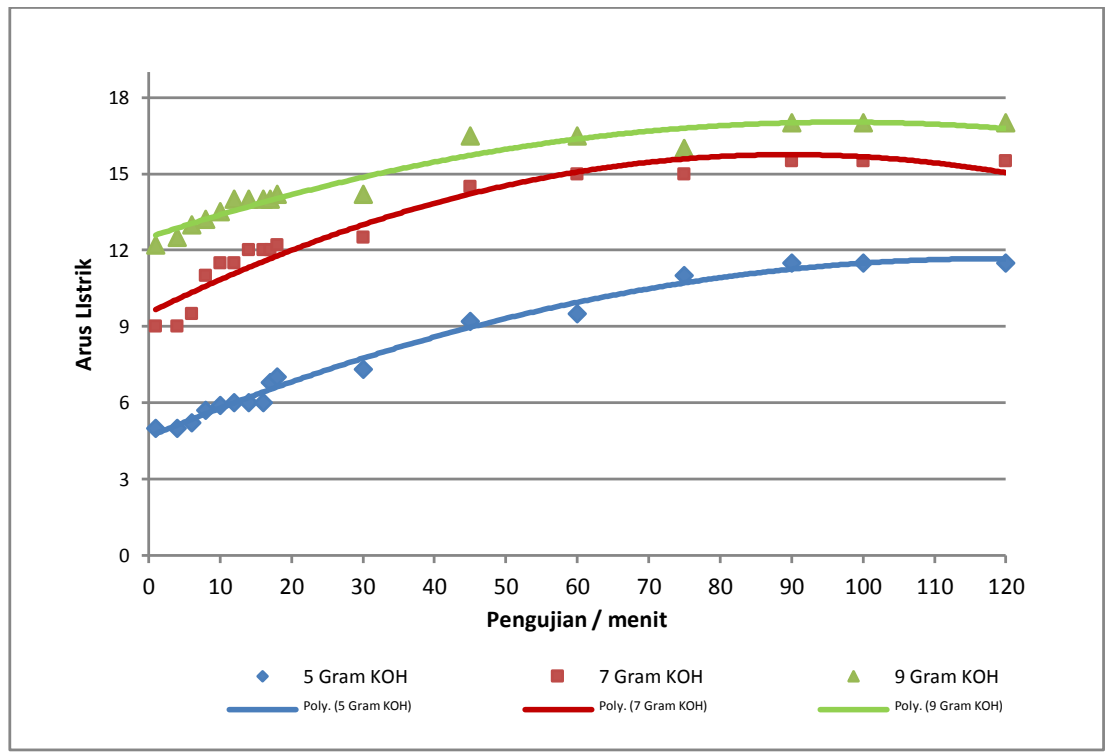

Gambar 5. Grafik Hasil Pengujian Arus Listrik

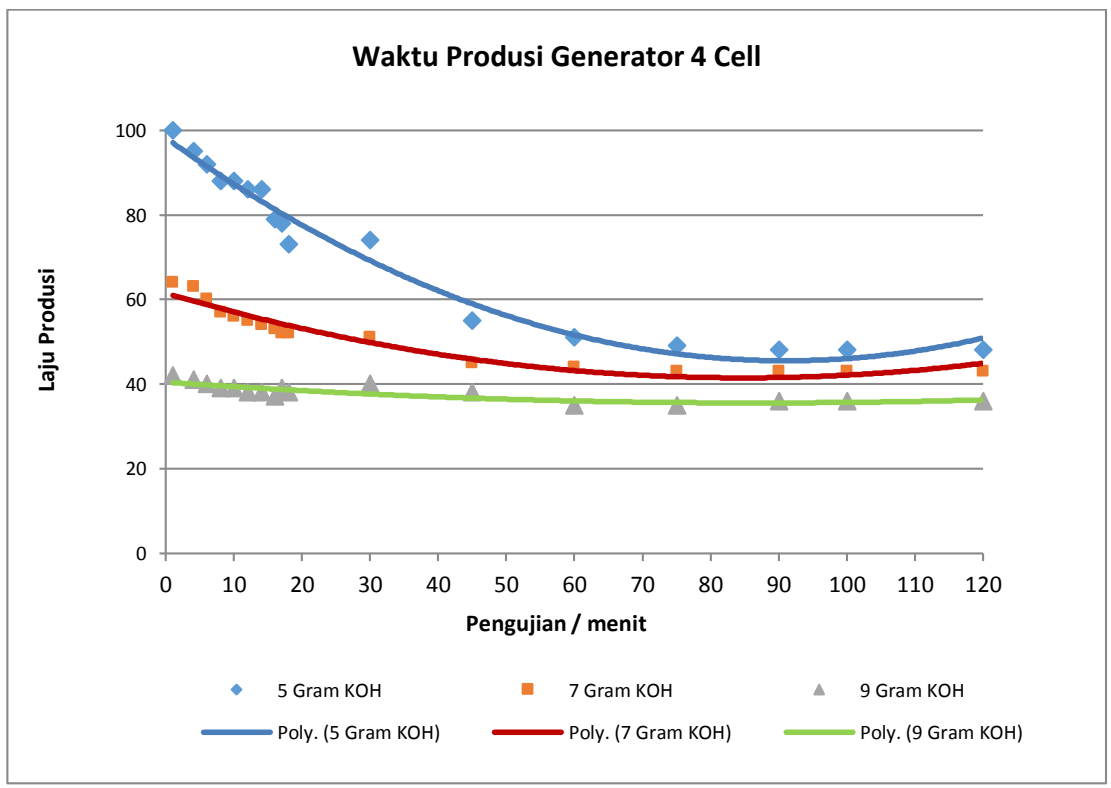

Gambar 6. Grafik Hasil Pengujian Produksi HHO 
Waktu dan lama serta perlakuan pengambilan data hasil uji generator pada Gambar 6 diambil bersamaan dengan hasil uji arus listrik pada generator HHO. Dari hasil uji gambar 6 diatas terlihat tren yang berbanding lurus dengan hasil pengujian arus yaitu pada gambar 5, dimana semakin besar arus atau energi listrik yang diberikan pada pengujian generator maka akan semakin besar laju prduksi gas HHO yang dihasilkan, karna jika arus listrik semakin besar pergerakkan ionion yang bekerja dalam generator $\mathrm{HHO}$ akan semakin cepat. Semakin cepat pergerakan ion-ion akan menimbulkan gesekkan antara ion yang semakin besar sehingga temperatur larutan semakin tinggi dan semakin lama suatu larutan bereaksi menyebabkan kondisi larutan akan semakin jenuh, sehingga berkurangnya laju produksi gas HHO serta menemukan titik stabilnya laju produksi gas HHO di menit ke 75 pada 5 dan 7 gram $\mathrm{KOH}$ jika dibandingkan dengan 9 gram $\mathrm{KOH}$ yang cendrung stabil dari awal waktu percobaan sampai akhir, jika tempratur semakin naik maka akan lebih banyak energi yang keluar disebabkan tidak adanya penyimpan panas sehingga berkurangnya kemampuan elektrolisasi pada generator yang berakibat terhadap ikut berkurangnya hasil produksi gas HHO dari awal percobaan sampai akhir percobaan.
Pada Gambar 7 diperlihatkan efisiensi dari generator untuk waktu percobaan selama 120 menit. Dari gambar 7 diatas terlihat trendline grafik yang memiliki karakteristik bahwa jumlah $\mathrm{KOH}$ yang sedikit (5 gram) memiliki nilai efisiensi yang paling tinggi dengan nilai rata-rata $89,39 \%$. Ini di sebabkan oleh jumlah produksi gas $\mathrm{HHO}$ yang dihasilkan pada saat menit 75 sampai 120 cendrung sama besar dengan jumlah $\mathrm{KOH} 7$ dan 9, sedangan energi yang di butuhkan (terlihat pada grafik gambar 5) hanya sedikit dibadingkan dengan penambahan 7 dan 9 gram KOH. Sehingga nilai efisiensi pada penambahan 5 gram $\mathrm{KOH}$ lebih tinggi.

Nilai efisiensi terendah terlihat pada penambahan 7 gram $\mathrm{KOH}$ yaitu senilai $72,29 \%$. Ini disebabkan karna rata-rata produksi gas $\mathrm{HHO}$ yang cendrung lebih sedikit dibandingkan dengan energi yang diperlukan pada saat elektrolisa terjadi. Sedangkan untuk nilai efisiensi dengan penambahan 9 gram $\mathrm{KOH}$ lebih besar dari 9 gram $\mathrm{KOH}$ disebabkan jumlah produksi gas HHO yang cendrung lebih stabil dari waktu menit pertama percobaan sampai akhir percobaan.

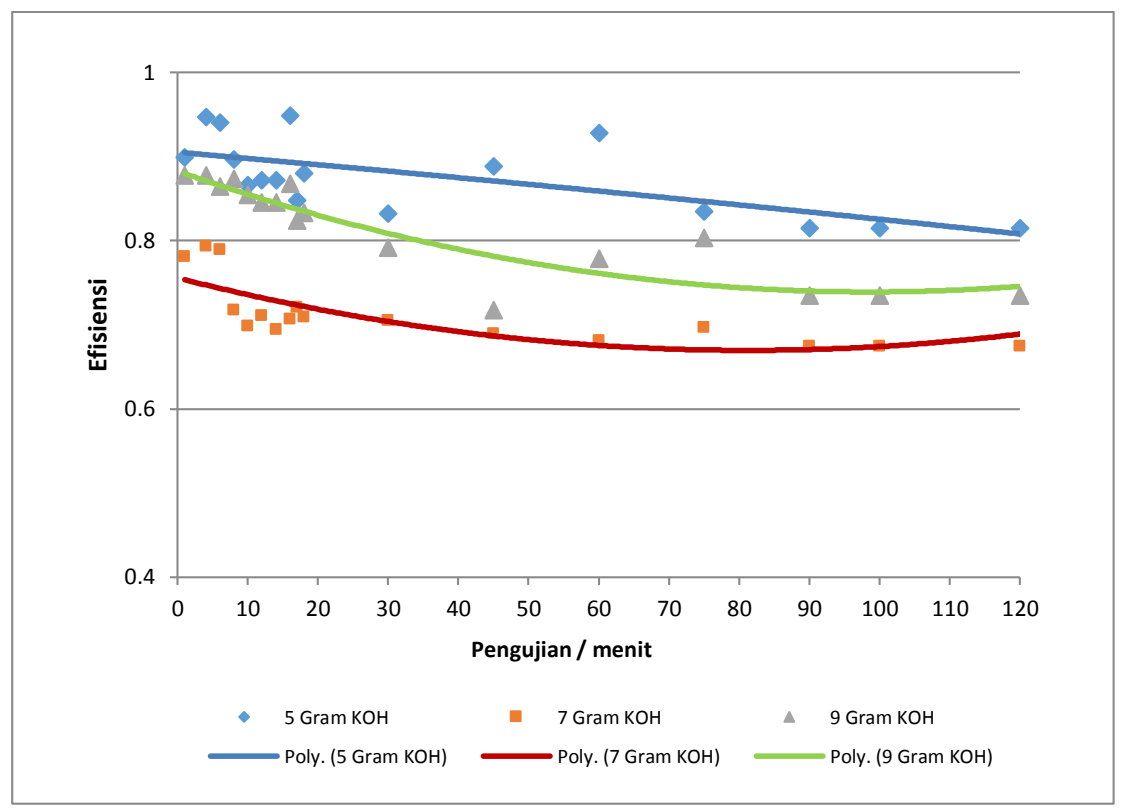

Gambar 7. Grafik Hasil Efisiensi Generator HHO 


\section{KESIMPULAN DAN SARAN}

Adapun kesimpulan dan saran dari penelitian ini adalah: (1) Dari hasil penelitian di atas membuktikan besarnya pengaruh jumlah $\mathrm{KOH}$ yang di tambahkan pada larutan elektrolisa HHO terhadap daya, laju produksi gas $\mathrm{HHO}$ dan nilai efisiensi. Jumlah produksi gas HHO terbanyak terdapat pada penambahan $\mathrm{KOH} 9$ gram serta produksi yang lebih stabil jika dibandingkan dengan penambahan 5 gram $\mathrm{KOH}$ yang cendrung menghasilkan sedikit gas $\mathrm{HHO}$ pada awal-awal terjadinya elektolisa. Ini akan menyebabkan kurang bagusnya jika gas yang dihasilkan langsung diaplikasikan pada kendaraan; (2) Penulis menyarankan, jika dari hasil pengujian di atas akan diaplikasikan pada kendaraan agar menggunakan penambahan $\mathrm{KOH}$ sebanyak 9 gram, karna produksi gas HHO lebih stabil dibandingkan dengan penambahan 5 dan 7 gram $\mathrm{KOH}$.

\section{DAFTAR PUSTAKA}

[1] A. Ammar dan Al-Rousan "Reduction of fuel consumption in gasoline engines by introducing HHO gas into intake manifold" fuel, Vol. 35, pp. 12930-12935.

[2] Based on JANAF Thermochemical Tables, NSRDS-NBS-37, (1971); Selected Value Note 270-3, 1968; and API Research Project 44, Carnegie Press, 1953. Heating values calculated.

[3] H. M. Cobb. Steel Product Manual: Stainless Steel. Warrendale P.A: Iron \& Steel Society, 1999.

[4] H. L. Guntur, S. B. Rasiawan, I. N. Sutantra, "Pengembangan Sistem Suplai Brown Gas Model 6 Ruang Tersusun pada Mesin Mobil 1300 cc dengan Sistem Karburator", Jurnal Teknik Mesin, Vol. 13, No. 1, 2011, pp. 13-17.

[5] K. S. Gaikwad, "Development of a Solid Electrolyte for Hydrogen Production". Thesis. Master of Science in Electrical Engineering Department of Electrical Engineering College of Engineering University of South Florida, 2004.

[6] Lowrie, Peter. W.E. Electrolytic Gas. http://waterpoweredcar.com /pdf.files/egas calculations.pdf, 2005.

[7] S. A. Musmar dan A. A. Al-Rousan, "Effect of HHO gas on combustion emissions in gasoline engines". Fuel, Vol. 90, pp. 3066-3070.

[8] Nofriyandi. R, "Studi eksperimen pengaruh penggunaan $\mathrm{KOH}$ terhadap performance generator HHO tipe dry cell berdiamensi 3.316 $\mathrm{mm}^{2}$ ". Dalam National Conference of Applied Sciences, Engineering, Business and Information Technology Politeknik Negeri Padang, 2016.

[9] Pusdatin ESDM. Handbook of Energy \& Economic Statistics of Indonesia). Jakarta, 2010.

[10] Pusdatin ESDM. Handbook of Energy \& Economic Statistics of Indonesia). Jakarta, 2011.

[11] D. Widyantara. "Pengaruh Penambahan Generator HHO dengan Variasi Rangkaian Generator HHO Seri dan Paralel Terhadap Unjuk Kerja Mesin Honda Supra X 125 PGMFI". Tugas Akhir, Institut Teknologi Sepuluh Nopember, Surabaya, 2011.

[12] Yilmaz, Ali Can., Erinc., Uludamar., Aydin Kadir, "Effect of Hydroxy (HHO) Gas Addition on Performance and Exhaust Emissions in Compression Ignition Engines". Hydrogen Energy, Vol. 35, pp. 11366-11372, 2010.

\section{BIODATA PENULIS}

Nofriyandi. R., S.Pd., M.T., memperleh gelar Sarjana Pendidikan (S.Pd), Program Studi Teknik Otomotif Fakultas Teknik [Universitas Negeri Padang], lulus tahun 2011. Tahun 2014 memperoleh gelar Magister Teknik (M.T) dari Program Rekayasa Konversi Energi, Jurusan Teknik Mesin [Institut Teknologi Sepuluh November]. Saat ini sebagai Staf pada Jurusan/Prodi Teknik Mesin [Universitas Dharma Andalas]. 